"Volume 14, No. 1, Juni 2020"

\title{
MEMAHAMI KAIDAH USHULIYAH LUGHAWIYAH PERSPEKTIF TIORI AHNAF
}

\author{
Oleh: \\ Faiz Zainudin \& Arif Hariyanto \\ Universitas Ibrahimy Situbondo, Indonesia \\ faizzainudd130587@gmail.com \& arifalrhandy@gmail.com
}

\begin{abstract}
:
The problem of innovation is a trigger factor in the religious disharmony, claims of truth occurs only on one side, and regard the other with false accusations and even accused as infidels. Heresy at the time still not Resolved, justruh become even more tapered and-so. They had perverted heretical propaganda through mass media like radio, fatwa commission, salebaran, and other writings, such accusations Surprisingly more precisely lead to the Expert Sunnah Wal Jama'ah. For that, it should be with the polemics of this kind needs be no specific response to concerns relating to issues that have been merasahkan and disrupt the comfort and harmony of religions, especially Islam in terms of legal analysis. The goal is that these problems can be solved by the decision of the best and can provide solutions that can diajalankan by the public, and can eliminate the unilateral truth of the allegations.Furthermore, to provide the best solution on the claims of heresy heresy, in society, the author gives an explanation which is very comprehensive in answering the issues around innovation with the proposition that qhat'i berlandasankan and accountable, in the form of alQuran and Hadith-Hadith sahih, but it is also the author gives a real understanding of what it is heresy and Islamic attitudes in response to this polemic. Because the moment is now so easy to claim someone on charges of heresy that ultimately leads to infidelity.

The design of the study is a research library research (literature study) using the method of qualitative analysis with deductive and descriptive way of thinking. The results of this study, is to assert that not all innovations are prohibited, senayampang heresy has qhat'i cornerstone arguments. Even the heretics also be recommended by the Sunnah of the Prophet. In addition to the understanding of the hadith also straighten often used as a reference by those who say all heresies heresy, as well as provide an understanding of how to determine the proper position on the hadith, as well as introducing a method to determine the hadith in order to understand haidits with true understanding. Based on the results of this study, recommended for groups who claim to truth as Islamic fundamentalist and liberal Islam should not only understand the hadith of the literal aspect dhahirnya alone or, if a hadith is understood from the aspects dhahirnya will certainly experience a
\end{abstract}

$$
\begin{array}{l|l}
\text { JURNAL LISAN AL-HAL } & 91
\end{array}
$$


fatal error kerana pemahamn like it was just owned by someone who have an interest or based on lust.

Keywords: Kaidah Ushuliyah, Teori Ahnaf, Ushul Fiqh, Lughawiyah

\section{A. Pendahuluan}

Para ulama ini tidak sepakat dalam menggunakan istilah-istilah untuk mengungkapkan arti yang subtansial dan juga pada metodologi yang mereka pakai dalam kajian karena perbedaaan tempat tinggal mereka, perbedaan persepektif dan tujuan mereka dalam penulisan dan penyusupan kitab mereka sendiri. Disamping itu terdapat dua metodologi dan terminologi kelompok mutakallimin dan kedua metode Ahnaf.

Dalam pandangan ulama Mutakallimin pembahasan dilakukan dengan pendekatan ilmu kalam dan penetapan ushul tersebut sesuai dengan cabang yang ditetapkan imam madzhab atau justru sebaliknya, yang termasuk kelompok mutakallimin antara lain: Mu'tazila, Syafi'iyah, dan Malikiyah dan kelompok Ahlu Sunnah. Mereka menetapkan kaidah atas dasar akal dan argumentasi, sedangkan yang bertentangan dengan rumusan akal dan dalil tersebut mereka tiadakan. Sedikit sekali mereka yang memiliki perhatian terhadap pembahasan furu' madhab kecuali ada tujuan tertentu.

Sementara metodologi ulama Hanafiyah adalah dengan memperhatikan penerapan furu' yang telah dirumuskan madhab terhadap kaidah-kaidah, sehingga mereka dapat menetapkan kaidah mereka sesuai dengan furu' yang mereka adopsi dari imam mereka. Apabial kaidah tersebut berlawanan dengan satu cabang dalam fikih. Seakan akan mereka menetapkan dasar-dasar fikih agar dianggap bahwa imam madhabnya mengikuti dasar-dasar fikih dalam merinci masalah dan menentukan hukum didalalmya. Hal itu kadang menyenbabkan mereka menetapkan yang asing bentuknya. Oleh karena itu dapat dilihat ushul dari ulama Hanafi depenuhi dengan furu', karena pada hakikatnya furu' itu adalah ushul bagi kaidah kaidah itu sendiri.

\section{B. Kaidah Pertama Adalah Dhalalah (penunjuk) Nash}

Nash syar'i atau perundang-perundangan wajib diamalkan sesuai dengan apa yang difahami dari ibaratnya (susunan kalimat) atau isyarah nash, dhlalah atau i'tiqadhiyahnya. Karena segala sesuatu yang difahami dari nash dari salah satu jaln yang empat tersebut, maka ini termasuk diantara madlul (yang ditunjuk oleh nash) sedangkan nash adalah hujjah atas dhlalah tersebut.

92 JURNAL LISAN AL-HAL 
Adapun penjelasan yang terperinci bagi kaidah ini, maka kaidah ini merupakan penjelasan terhadap maksud masing-masig dari empat jalan diantaranya adalah ${ }^{1}$

\section{Ibarat al-Nas}

Yang dimaksud dengan ibarat al-nash adalah shighatnya yang terdiri dari beberapa satuan kata (mufradat) dan kalimat. Sedangkan yang dimaksud dengan makna yang difahami dari ibarat nash ialah makna yang segera dapat difahami dari bentuk lafad tersebut. makna tersebut adalah yang dimaksudkan dari susunan kalimatnya. Sepanjang makna itulah yang dhahir pemahamannya dari sighat nash, sedangkan nas disusun untuk menjelaskan dan menetapkannya, maka ia yang ditunjuk oleh ibarat nash yang juga disebut sebgai makna literal bagi nash. Jadi dhalah ibarat adalah dhalalh shigat terhadap makna yang segera dapat difahami, baik makna tersebut dikehendaki dari redaksinya secara ashalah (asli) atau tab'an (pengikutan). ${ }^{2}$

Contoh dari dhalalh ini sangat banyak sekali, dhalah ini menghendaki pembentukan suatu hukum dan menyusun bahasa serta redaksinya agar supaya dapat menunjukkan pengertian yang jelas terhadap hukum tertentu. Setiap teks baik dalam undang-undang syar'i maupun undang-undang positif. Dan terkadang pula disamping makna tersebut juga menunjukkan makna lain berdasarkan isyarat, dhalah ataupun iqtidha' dan kadang pula tidak mengandung makna lain. Oleh karena itu tak perlu mennjukkan banyak contoh oleh nash tersebut, hanya akan dijelaskan dengan sebagian contoh saja yang dapat memperjelas dari adanya perbedaan antara yang dimaksud dari susunan kalimat baik yang ashalah atau tab'an, seperti dalam firman Allah

$$
\text { وَأَحَلَّ اللَّهُ الْبَيْعَ وَحَرَّمَ الرِبِّا }
$$

Artinya: "Padahal Allah menghalalkan jual beli dan mengharamkan riba" (Q.S. al-baqarah ayat 275).

Teks ini menujukkan dhalah yang jelas atas dua makna, yang mana makna tersebut sama-sama dikehendaki dari kalam tersebut yaitu pertama, bahwasanya hukum jual beli dihalalkan sedangkan hukum riba diharamkan, kedua makna tersebut dapat difahami dari susunan kalimat tersebut dan dimaksudkan dari susunannya akan tetapi makna yang pertama dikehendaki secara ashalah karena ayat tersebut dikemukakan untuk membentah orang-orang yang mengatakan bahwasanya jual buli

\footnotetext{
${ }^{1}$ Abdul Wahab Khallaf, Ilmu Ushul fiqh, (Dar al-Ilmi, cet II, 1978), 144.
}

2 Ibid 
sama dengan riba sedangkan makan yang kedua dimaksudkan secara tab'an karena untuk menafikan adanya persamaan diikuti dari penjelasan hukum-masing-masing dari keduanya, sehingga dari perbedaan hukum tersebut dapat diambil kesimpulan bahwa kedua hal tersebut tidaklah sama. $^{3}$

\section{Isyarat al-Nash}

Yang dimaksud dari pengertian Isyarat al-nash adalah makna yang segera tidak dapat difahami dari lafadh-lafadnya, tidak pula dimaksud dari susunan kalimatnya. Akan tetapi makna tersebut memiliki makna yang lazim (terikat) bagi makna yang segera dapat difahami dari kafadnya. Jadi ibarat al-nas adalah makna yang ditunjuki oleh lafad melalui cara iltizam. Dengan demikian dhalalh nash terhadap makna tersebut melalui isyarah bukan ibarat.4

Kemudian jika dilihat dari segikela zimannya kadangkala jelas kadangkala maknanya tersembunyi, oleh karena itulah mereka berkata: "sesungguhnya sesuatu yang di isyarahkan oleh nash terkadang pemahamanya membutuhkan penalaran yang mendetail dan penelaran yang ekstra". Terkadang pula dapat difahami dengan pemikiran yang sederhana. Jadi dhalah isyarah adalah dhalalah

Nash terhadap makna yang lazim bagi suatu yang difahami dari ibaratnya, namun tidak dimaksud dari susunanya. Isyarah al-nash ini membutuhkan pemahaman dan perenungan yang ekstra atau sederhana saja, tergantung dari letak kejelasan atau kesamaran lafad tersebut. contoh dari dhalalah al-nash sebagaimana firman Allah

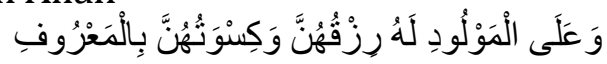

Artinya: "Dan kewajiban ayah member makan dan pakaian kepada para ibu dengan cara yang makruf" (Q.S. al-baqarah ayat 233)

dari ibarat al-nash dapat diambil sebuah pemahaman bahwasanaya nafkah para ibu baik makanan maupun pakaian adalah wajib bagi seorang ayah, karena sesungguhnya pengertian inilah yang segera cepat difahami dari lafad-lafadnya, selain itu dapat difahami dari segi ibarat al-nash bahwasanya ayah tidak berserikat dengan siapapun untuk memberikan kewajiban nafakah pada anak-anaknya, karena anak adalah milik ayah bukan milik orang lain.

Kalau sekiranya ayah dari kalangan suku Quraisy sementara ibunya bukan dari suku Quraisy maka posisi anaknya adalah untuk ayah yang

${ }^{3}$ Asy Syarkhasiy , Ushul al-Syarkhasiy, (Libanon: Bairut, cet II, 1993, Juz I), 242.

${ }^{4}$ Badruddin, Bahrul Muhith fi Ushul Fiqh, (Libanon: Dar al-kutub al-'Ilmiyah, 2000, Juz IV), 234.

94 JURNAL LISAN AL-HAL 
bersuku Quraisy. Begitu pula bilamana seorang anak memiliki harta, maka harta tersebut milik ayahnya. Hukum-hukum yang semacam inilah diambila dari isyarah al-nash disebabkan pada lafad nash terdapat keterkaitan seorang anak dengan ayahnya dengan huruf lam yang mempunyai arti takhsis dan penghususan inilah disebutkan dalam sebuah hadits

Artinya: "kamu dan hartamu milik ayahmu"5

$$
\text { أَنْتَنَ وَمَالْلَكَ لِأَبِيكَ }
$$

Dari kelaziman penghususan makna ini adalah tetapnya hukumhukum tersebut. hal itu merupakan hukum yang lazim bagi suatu makna yang difahami dari ibarat nash, namun tidak dimaksud dari susunannya, oleh karena inilah maka pemahamannya adalah dari isyarah al-nash bukan dari ibarah al-nash.

\section{Dhalah nash}

Yang dimaksud dangan dhalah nash adalah makna yang dapat difahami dari spirit nash. Jika ibarah al-nash menunjukakkan suatu kasus karena ada illat 6 yang menjadi dasar hukum dan ada kasus lain yang ditemukan itu sama dalalm illat hukumya atau bahkan melebihi lagi, dan persamaan atau lebihnya itu segera dapat difahami semeta-mata difahami tanpa membutuhkan ijtihad dan qiyas, maka secra bahasa nash tersebut dapat difahami bahwa ada dua kasus yang menyangkut pada nash tersebut, sedangkan hukum yang ada di mantuq ${ }^{7}$ itu tetap pada mafhum karena kesesuain illat baik persamaannya sejajar atau bahkan melebihi contoh dari dhalalah nash seperti dalam firman Allah

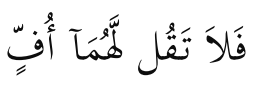

Artinya: "Maka janganlah kamu mengatakan kata "uff" kepada mereka" (Q.S. al-Isra' ayat 23).

Dari ibarah al-nash ini menunjukkan terhadap larangn mengucapkan kata uff pada kedua orang tuanya. Yang menjadi illat diharamkan mengucapkan kata uff karena menyakiti hati. Kemudian ada bentuk lain yang melebihi rasa sakitnya dari pada mengatakan uff seperti VII), 428.

${ }^{5}$ Abu Bakar al-Baihaqi, Sunan Kubra al-Baihaqi, (Mekkah: Darl al-Baz, 1994, Juz

${ }^{6}$ Yang dimaksud dengan illat adalah suatu sifat yang dijadikan dujadikan sebuah hukum pada hukum ashal dan juga sifat tersebut dijumpai pada fara'. (Abdul Wahab Khallaf), 60.

7 Yang dimaksud dengan mantuq adalah makna yang ada pada lafad tersebut, sedangkan yang dimaksud dengan mafhuh adalah makna yang tidak ada pada lafad tersebut (makna yang tersirat), Syekh Zakariaya al-Anshariy, Ghoyatul Wusul, (Surabaya: al-Hidayah), 36. 
memukul dan mencaci maki, sehingga dapat segera difahami bahwa hal tersebut juga dilarang. ${ }^{8}$ Contoh lain, seperti dalam firman Allah yang lain

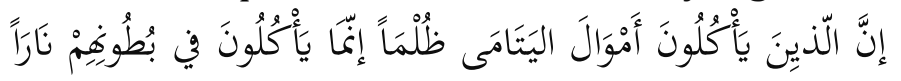

Artinya: "Sesungguhnya memakan harta anak yatim secara zdalim, sebenarnya mereka itu menelan api sepenuh perut mereka" (Q.S. al-Nisa' ayat 10)

Dari ibarah al-nash dapat difahami bahwa haram bagi para penerima wasiat untuk memakan harta anak yatim secara zdalim dan juga dapat difahami dari dhalalahnya haram memberikan harta anak yatim pada orang lain, haram membakarnya, haram merusak dan memusnahkannya, karena hal-hal tersebut sama halnya memakan harta anak yatim tersebut. maka keharaman memakan harta anak yatim berdasarkan ibarah al-nash sedangkan merusak, mebakar, dan menghancurkan itu berdasarkan dhalalah al-nash. ${ }^{9}$

Perbedaan antara dhalalah al-nash dengan qiyas adalah persamaan mafhum yang sesuai dengan mantuq dapat difahami semata-mata dengan cara memahami kebahasaannya tanpa tergantung pada ijtihad dan istimbath, sedangkan persamaan sesuatu yang diqiyaskan dengan maqis 'alih (yang diqiyaskan) tidak dapat difahami illatnya tanpa melalui ijtihad dan istimbath. 10

\section{Iqtidha al-Nash}

Yang dimaksud dengan iqtidha al-nash adalah makna yang tidak dapat difahami kecuali dengan cara menaqdir kalimat lain. Dalam shighat nash tidak terdapat lafad yang menunjukkan makna itu, akan tetapi kesahihan shighatnya serta kelurusan pengertiannya menuntut keberadaanya, atau kebenarannya dan kesesuainnya dengan kenyataan menuntutnya, contoh dari iqtidha al-nash pada sabda Nabi Muhammad

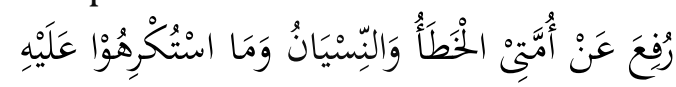

Artinya: "Telah diangkat dari ummatku kesalahan, lupa dan sesuatu yang mereka dipaksakan atasnya"11

Kalimat ini secara dhahirnya menunjukkan diangkatnya suatu perbuatan salah apabila dalam keadaan lupa atau dalam keadaan terpaksa. Ini adalah makna yang tidak sesuai dengan kenyataan, karena apabila

${ }^{8}$ Al-Raziy, (Tafsir al-Raziy, Juz II, Maktaba al-Syamilah), 199.

${ }^{9}$ Hasan bin Muhamad al-'Athar, (Hasyiyah al-'Athar, Juz II, Maktaba al-Syamilah), 275.

${ }^{10}$ Loc Cit Abdul Wahab Khallaf.

${ }^{11}$ Jalaluddin asy-Suyuti, (Jami' al ahadits, Juz XIII, Maktaba Syamilah), 139.

96 JURNAL LISAN AL-HAL 
perbuatan sudah terjadi maka tidak akan diangkat susuna kalimat ini menuntut untuk dikira-kira yang pas, lalu jika di taqdhirkan lafad lain menjadi:

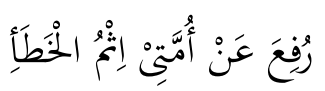

Atinya: "Diangkat dari ummatku dosa kesalahan"

Kalau misalnya dosa yang dibuang dituntut untuk ditakdhirkan oleh kesahihan makna nash tersebut, kemudian yang ditunjuk oleh nash di sebut iqtihda'

Dari uraian diatas jelaslah apa yang telah dijelaskan bahwasanya setiap makna yang difahami nash dengan salah satu dari yang empat, maka termasuk hal yang dituntut oleh nash dan nash tersebut menjadi hujjah dari makna lafad. Karena sesunguhnya makna yang dapat segera difahami dari lafadnya dimaksudkan dari susunan redaksi lafad tersebut, sedangkan makna yang diambil dari isyarah al-nash diambil makna yang lazim pada lafad itu yang ditunjuk secara iltizam oleh nash, selanjutnya makna yang diambil dari dhalalah nash makna yang dapat difahami dari sepirit al-nash, kemudian makna yang dapat difahami secara iqtidha' adalah makna dharuriy dari suatu lafad.

\section{Mafhum Mukhalafah}

Apabila nash syar'i menunjukkan suatu hukum pada suatu tempat yang dibatasi, sebagaimana dibatasi dengan suatu sifat atau disyarati dengan syarat, diabatasi dengan suatu keadaan maksimal, dibatasi dengan hitungan maka hukum yang dibatasi tersebut dinamakan dengan mantuq, sedangkan hukum yang tidak ada batasannya maka dikatakan sebagai mafhum mukhalafah.

Pengertian secara kaidahnya adalah nash syar'i tidaklah mempunyai dhalalah atas suatu hukum yang difahami yang mana hukum tersebut berbeda dengan mantuqnya. Akan tetapi hukum yang difahami berbeda yang disebutkan dalam nash dan tidak disinggung-singung, diketahui dengan dalil lain maupun dalil syar'i berupa ibahah asliyah. Sebagaiman contoh dalam firman Allah

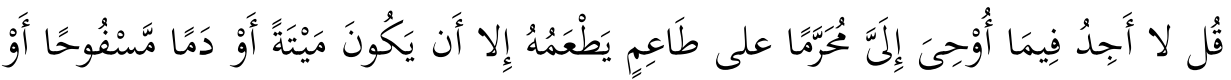

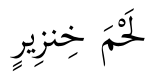

Artinya: "Katakanlah: tidaklah aku peroleh dalam wahyu yang diwahyukan kepadaku, sesuatu yang diharamkan bagi orang yang hendak 
memakannya, kecuali kalau makanan itu bangkai, darah yang mengalir atau danging babi" ${ }^{12}$ (Q.S. al-an'Am ayat 145).

Yang dikatakan didalam nash adalah keharaman darah yang mengalir, sedangkan penghalalan darah yang tidak mengalir merupakan mafhum yang berbeda dari apa yang dikatakan didalam nash. Dari ayat itu tidak ditunjuk kehalalan akan tetapi kehalalan itu dapat ditangkap berdasarkan ibahah asliyah, atau dengan dalil lain seperti sabda Nabi Muhammad saw.

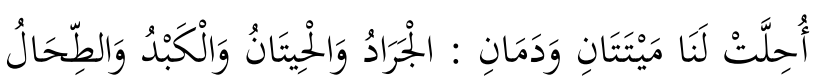

Artinya: "Dihalalkan bagi akmi dua bangkai dan dua darah yang dimakdu dua bangkai adalah ikan dan belalang, sedangkan dua darah adalah hati dan limpa"13

Mengenai penjelasan yang terperinci dari mafhum mukhalafah ini memiliki beberapa macam yaitu terbagi menjadi lima:

1. Mafhum sifat

sebagaimana dalam firman Allah dalam menjelaskan wanita-wanita yang diharamkan untuk diknikahi

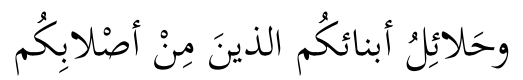

Artinya: "Dan istri-istri anak kandungmu (menantu)"(Q.S. an-Nisa':

Mafhum mukhalafah dari ayat ini adalah istri-istri anak yang tidak sekandung seperti anak sepenyususan ${ }^{14}$

Sebagimana sabda Nabi lagi

$$
\text { فِي السَّائِمَة زَكَاةِ }
$$

Artinya: "pada binatang ternak yang digembalakan ada zkatnya"

Mafhum mukhalafah dari hadist ini adalah binatang ternak yang makanannya dicarikan tidak dengan di gembala maka tidak ada zakatnya. ${ }^{15}$

2. Mafhum ghayah

Lafad yang terdapat ghayahnya dapat diambil mafhum mukhalafah sebagimana firman Allah swt.

12 Abu al-Qhasim al-Husain, (al-Mufradad fi gharib al-Quran, Juz I, Maktaba Syamilah), 83.

${ }^{13}$ Abu Abdillah Asy Syafi'i, Musnad Asy-Syafi'i, (Libanon: Bairut, Juz I), 340.

${ }^{14}$ Abu Hayyan Muhammad, (Tafsir Bahrul Muhith, Juz IV, Maktaba Syamilah), 94.

15 Aliy Muhammad al-Amudhiy, al-Ihkam fi Ushulil Ahkam, (Libanon: Bairut, cet I, 2004, Juz III), 79.

98 JURNAL LISAN AL-HAL 


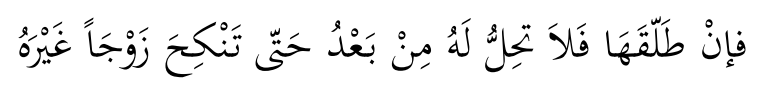

Artinya: "Kemudian jika sang suami mentalaknya (sudah talak yang kedua) maka perempuan itu tidak halal baginya hingga dia kawin dengan suami yang lain" (Q.S. al-Baqarah ayat 230).

Mafhum mukhalafnya adalah apabila wanita yang diceraikan tiga kali menikah dengan laki-laki lain selain yang menceraikan maka halal untuk dinikahi

contoh lain pada firman Allah

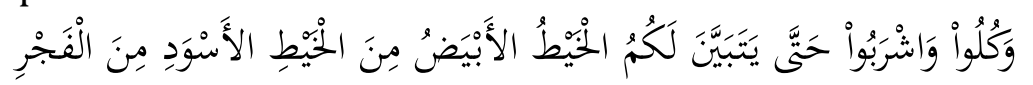

Artinya: " Dan makanlah dan minumlah, sehingga terang bagimu benang yang putih dan benang yang hitam yaitu fajar" (Q.S. al-Baqarah ayat 187).

Mafhum mukhalafahnya adalah apibila telah jelas benang putih dan benang hitam yaitu fajar.

3. Mafhum Syarat

Syarat juga termasuk perangkat dari mafhum mukhalafah sebagaimana firman Allah

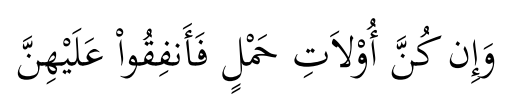

Artinya: "Dan jika mereka (istri-istri yang sudah ditalaq) itu sedang hamil, maka berikanlah kepada mereka nafkahnya hingga mereka bersalin" (Q.S. al-Thalaq ayat 6)

Mafhum mukhalafahnya dari ayat ini adalah jika istri yang ditalaq tersebut itu dalam keadaan hamil, maka tidak harus nafkahnya

Contoh lain seperti firman Allah

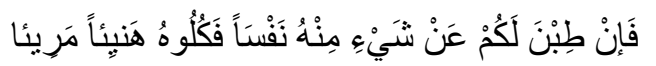

Artinya: “Kemudian jika mereka menyerahkan kepadamu sebagian dari maskawin itu dengan senang hati, maka makanlah (ambillah) pemberian itu (sebagi makanan) yang sedap lagi baik akibatnya"

(Q.S. an-Nisa' ayat 4)

\section{Mafhum adad}

Adat merupaka salah satu alat yang dapat diambil mafhum mukhalafah hal ini telah dicontohkan dalam al-Quran

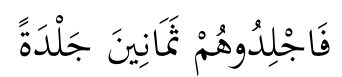

Artinya: "Maka deralah delapan puluh deraan" (Q.S. an-Nur 4)

Mafhum mukahalafahnya adalah yang lebih sedikit ada yang lebih banyak dari delapan puluh

Contoh lain 


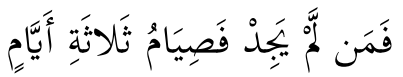

Artinya: "Maka barang siapa yang tidak menemukan (binatang kurban atau tidak mampu), maka wajib berpuasa tiga hari dalam masa haji" (Q.S. al-Baqarah : 196).

\section{Mafhum Laqob ${ }^{16}$}

Laqob salah satu perangkat yang dapat diambil mafhum mukhalafah sebagimana telah dicontohkan dalam firman Allah

$$
\text { عُحَمَّدْ رَسُولُ اللَّدِ }
$$

Artinya: "Muhammad adalah Rasulullah" (Q.S. al-Fath: 29)

Rasulullah

Mafhum mukhalafahnya adalah selain Muhammad bukan

\section{Lafad 'Am}

Lafad 'am secara bahasa adalah lafad yang mencakup terhadap sesuatu yang berbilangan, baik itu berkaitan dengan lafad atau pun tidak. lafad 'am menurut definisi istilah ialah lafad yang mencakup terhadap semua sesuatu yang layak dari afrod-afrodnya (person-personnya). ${ }^{17}$ Didalam kitab al-Mahsulnya Imam ar-Razi memberikan sebuah pengertian tentang 'am yaitu lafad yang mengahabiskan terhadap sesuatu yang layak, dengan memandang satu objek. Semisal lafad rojulun (orang laki-laki) maka lafad ini mencakup kepada semua orang laki-laki. ${ }^{18}$ Hal ini berbeda dengan lafad mutlak, sebab lafad mutlak yang dijadikan ukuran adalah mahiyahnya (hakikatnya) sehingga jika diaplikasikan pada lafad rajulun yang dilihat bukan mencakup laki-laki secara keseluruhan akan tetapi yang dipandang hakikat dari semua laki-laki. ${ }^{19}$

\section{Bentuk-Bentuk Lafad Umum}

Ada beberapa tanda yang menunjukkan lafad umum yaitu ${ }^{20}$

a. Lafad jamak yang dima'rifatkan oleh al jinsi atau dimudhafkan

Tiap-tiap lafad yang bentuknya jama' kemudian dima'rifatkan dengan al maka menunjukkan umum baik itu bentuknya jamak mudzakar

\footnotetext{
16 Para ulama Ushul fikih tidak mempergunakan mafhum laqab sebagai hujjah untuk dijadikan mufhum mukhalafah karena sesungguhnya penyebutan tidak dimaksudkan untuk membatasi, tidak pula untuk mentakhsis dan tidak pula untuk membatasi dari lainnya.(Abdul Wahab Khallaf). 155.

${ }^{17}$ Asy-Syarkhasiy, Usul al-Syarkhasiy, (Libanon: Bairut, 1993, Juz I), 125.

18 Al-Raziy, al-Mahshul, (Libanon: Bairut, Juz I), 34.

${ }^{19}$ Wahba az-Zuhaili, Ushul fiqh al-Islami, (Libanon: Dar al-Fikr, Juz I), 238.

20 ibid

$100 \mid$ JURNAL LISAN AL-HAL
} 
salim seperti lafad المسلمين atau lafadnya berbentuk jamak dan muannas salim contoh المسلمات atau lafanya jamak taksir semisal lafad الذنوب. Begitu pula lafad jamak yang dimudafkan itu menunjukkan keumuman lafad خذ من أمولهم صدقة (التوبة 103/9) tersebut seperti dalam firman Allah

b. Lafad mufrad (bermakna satu) yang dima'rifatkan dengan al istigraq dan dima'rifatkan dengan dimudhafkan.

Lafad yang mufrad (bermakna satu) bilamana dima'rifatkan dengan al istigraq maka lafad tersebut menunjukkan 'am (umum) seperti yang وأحل الله البيع : telah difirmankan oleh Allah dalam surat al-baqarah ayat 278 dari ayat mencakup terhadap bentuk jual beli dan praktek riba apapun. Contoh yang kedua adalah lafad mufrad yang dima'rifatkan dengan sebab idhafah yaitu dalam hadist Nabi yang menerangkan tentang هو الطهور ماؤه الحل ميتته ini menunjukkan bahwa tiap-tiap bangkai yang ada dilaut jika dikonsumsi hukumnya halal.

c. Isim nakirah yang redaksinya naïf, nahi atau syarat.

Isim nakirah bilamana redaksi kalamnya terdiri dari nafi, nahi dan syarat maka itu semua menunjukkan keumuman, hal ini dapat dilihat dari contoh firman Allah yang menunjukkan nafi didalam surat al-baqarah ayat 256: لا اكراه في الدين. Contoh yang kedua dalam redaksi nahi pada ayat al-

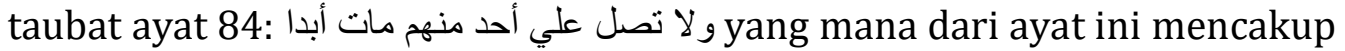
terhadap semua orang-orang munafik, karena ada kalimat (آلآد) pada redaksi nahi. Contoh yang ketiga ditunjukkan pula oleh firman Allah (فاسق) ayat ini menunjukkan keumuman pada ayat جاءكم فاسق بنباء فتبينوا karena ayat ini diawali huruf syarat.

d. Isim Maushul

Lafad-lafad yang dalam redaksinya terdiri dari isim maushul maka kalam tersebut menunjukkan lafad umum karena isim maushul tersebut mengandung lafad ' $a m$, sedangkan bentuk-bentuk isim mashul adalah lafad

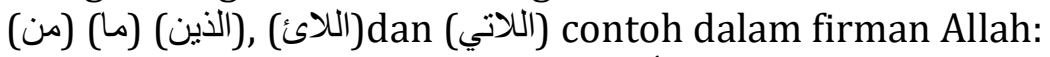

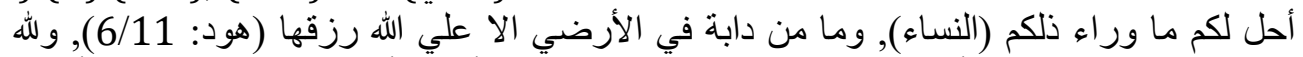

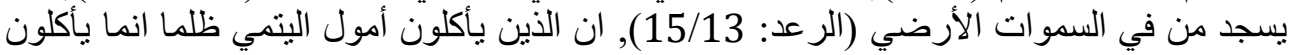

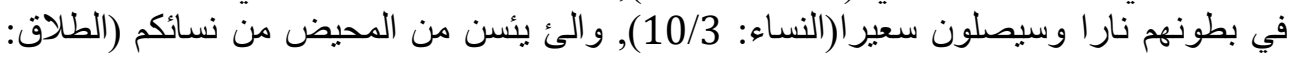

e. Isim istifham

Bilamana dalam redaksi terdapat isim-isim istifham maka lafad tersebut menunjukkan umum sebab isim-isim istifham termasuk

${ }^{21}$ Ahmad bin Husen bin 'Ali al-Baihaqi Abu Bakar, Sunan al-Shugra, maktabah alDar, 1989, Juz I, hal 151. 
perangkat-perangkatnya lafad ' $a m$, bentuk-bentuk lafad isim-isim istifham seperti: (من), (ماذا), (مني), dan (أين), hal ini telah dicontohkan dalam

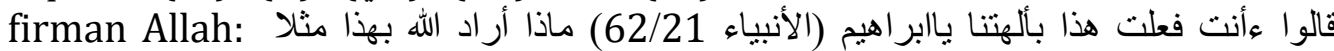

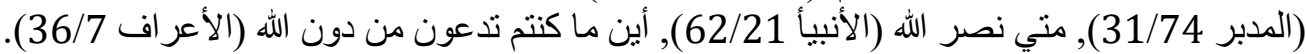

f. Lafad al-jumu,'

Jika dalam susunan kalam terdi dapat lafad al-jumu' semisal lafad (جميع), (كلشر), (كعاشر), (كافة), dan (كعرة), hal ini telah dicontohkan dalam كل مرئ بما كسب رهين(الطور: أم يقولون نحن جميع منتصر (القمر: 21/54).:عirman Allah) $(21 / 52$

g. Macam-macam lafad 'am

Dilihat dari segi macam-macam lafad 'am yang sudah mashur itu ada tiga macam yaitu

a) 'am yuridu bihi al-'umum

Yakni lafad 'am yang mencakup terhadap semua lafad yang tidak ada qorinah (indikasi) untuk mentakhsis lafad 'am tersebut. seperti yang telah dicontohkan dalam firman Allah dalam surat Hud ayat 11:

dari ayat ini menunjukkan umum dan tidak ada pen-takhsisan.

b) 'am yuridu bihi al-khusus

Yakni lafad 'am yang mencakup terhadap semua lafad namun ada qorina (indikasi) yang dapat mentkhsis lafad 'am tersebut, sehingga lafad tersebut tidak menunjukkan umum lagi, semisal dalam firman Allah pada al-'Imron ayat 97: ولله علي الناس حج البيت من الستطاع اليه سبيلا dari ayat ini menunjukkan umum akan tetapi ditkhsis dengan akal sehingga haji itu hanya tertentu pada orang-orang mukallaf sedangkan anak kecil dan orang gila tidak masuk dalam kategori ayat ini.

c) 'am mutlak

Yang dimaksud dari am mutlak adalah lafad 'am tidak disertai dengan qorinah yang tidak menunjukkan keumuman lafad serta tidak pula menunjukkan ke khususan suatu lafad. Dari adanya 'am mutlak ini banyak ulama yang berselisih apakah 'am ini menunjukkan qhat'iy atau dhanniy, kebanyakan ulama mengatakan dari golongan Syafi'iyah, Malikiyah dan Hanabilah 'am mutlak itu dhanniy, sementara golongan hanafiyah dan Mu'tazilah berpendapat 'am mutlak adalah qhat'iy, yang dimaksud qhat'iy disini jika lafad 'am masih belum di-takhsis terhadap sebagian afrodnya tapi jika telah mengalami takhsis pada sebagian afrodnya bukan qhat'iy lagi melainkan dhanniy

$102 \mid$ JURNAL LISAN AL-HAL 
Argumentasi yang dikemukakan oleh jumhur yakni tiap-tiap lafad 'am memungkinkan untuk ditakhsis sehingga ada sebuah perkataan dari ulama:

dan kebanyakan ayat dalam al-Quran telah mengalami takhsis walaupun ada juga yang tidak mengalami takhsis tapi itu sangat minim. Argumantasi yang telah di lontarkan oleh ulama Hanafiyah bahwa lafad 'am memang sengaja diletakkan untuk menunjukkan umum maka dengan demikian umum telah menjadi sebuah keharusan kecuali kalau memang ada dalil yang mentakhsis ayat tersebut.

2. Konsekuwensi terjadinya perbedaan didalam dhalalah 'am

Terjadinya perbedan dikalangan ulama menimbulkan dampak yang signifikan pada dalalah 'am didalam dua persoalan antara lain sebagai berikut:

a. Men-takhsis lafad 'am yang qath'i dengan dalil dhanniy

Bilamana terdapat lafad 'am dalam al-Quran maupun Hadist apakah diperbolehkan di-takhsis dengan dalil dhanniy seperti hadist ahad ${ }^{22}$ dan qiyas, $^{23}$ maka dari sini terdapat perbedaan dikalangan ulama. Pendapat pertama yang dimotori oleh golongan hanafiyah mengatakan tidak boleh lafad am ditakhsis dengan dalil dhanniy, dengan alasan bahwasanya dalalah lafad 'am terhadap afrad-afradnya adalah qhat'i dan keqhat'ian alquran dan hadsit mutawatir tidak diperkenankan untuk ditakhsis dengan dalil dhanniy. Pendapat kedua yang dikumandangkan oleh jumhur memperkenankan untuk ditakhsis alasan yang dijadikan dasar oleh mereka yaitu dalalah 'am pada afrad-afrodnya adalah dhanniy dengan demikian boleh mentakhsis lafad 'am dangan dalil dhanniy semisal hadist ahad dan qiyas.

Berdasarkan pendapat yang telah dikemukakan diatas ulama' Hanafiyah mengharamkan penyembelihan hewan yang tidak disebut nama Allah sebagaimana telah tertera dalam al-quran pada surat al-an'am ayat 121:

ولا تأكلوا منا لم يذكرسم الله عليه dan tidak dapat ditakhsis dengan hadist Nabi

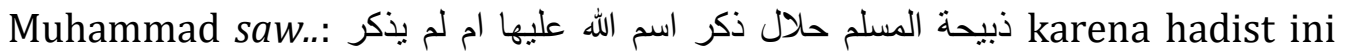
dianggap hadist ahad sementara kedudukan hadist ahad itu dhanniy, lain lagi dengan pendapatnya ulama dari golongan Syafi'iyah yang

22 Hadist ahad adalah hadist yang diriwayatkan perorangan, dua orang sekelompok yang tidak sampai pada batasan jumlah mutawatir. (Abdul Wahab Khallaf, Ilmu Ushul Fiqh, Dar 'Ilmi), 42.

${ }^{23}$ Qiyas adalah menyamakan kasus yang tidak ada nasnya dengan kasus yang sudah ada dalilnya dikarenakan ada persamaan illat hukum. (Abdul Wahab Khallaf), 52. 
memperbolehkan memakan sembelihannya orang muslim sekalipun dia sengaja meninggalkan bacaan tasmiyah karena mereka mentakhsis keumuman al-quran yang dhanniy dengan dalil yang dhanniy pula.

b. Terjadinya pertentangan antara lafad 'am dan khas

Ulama dari golongan Hanafiyah menghukumi terhadap persolan ini sebagai pertentangan yang harus untuk dilakukan penyelesaian. Mereka memberikan subuah penjelasan bahwa jika datangnya lafad khas itu tidak lambat dari lafad 'am maka lafad khas tersebut dapat mentakhsis lafad 'am, namun jika datangnya lafad khas itu lambat dari lafad 'am maka kedudukan dari lafad khas dapat menasakh lafad 'am tersebut. hal ini berbeda dengan pendapatnya mayoritas ulama yang berpendapat tidak menghukumi adanya pertentangan, mereka memberlakukan hukumnya masing-masing, yang dijadikan alasan oleh mereka disebabkan lafad 'am adalah lafad yang dhanniy sedangkan lafad khas adalah lafad yang qhat'i sementara antara lafad dhanniy dan qhat'i

3. Mentakhsis lafad 'am

Yang dimaksud dengan mentakhsis lafad 'am adalah membatasi lafad dari sebagian afrod-afrodnya. Didalam al-Quran maupun hadist banyak sekali lafad am yang ditakhsis semisal lafad An-Nas pada ayat

$$
\text { وله علي الناس حج البيت من الستطاع اليه سبيلا }
$$

hanya tertentu pada orang-orang mukallaf saja sedangkan anak kecil dan orang gila tidak masuk pada ayat ini.

4. Mukhassis yang berdiri sendiri (mustaqil)

Yang dimaksu mukhassis mustaqil adalah suatu penghususan yang tidak beriringan dengan lafad 'am itu sendiri, dan Ini memiliki enam macam yaitu

a. Ditakhsis dengan pengetahuan melalui panca indara

Syara' mendatangkan dengan lafad umum kemudian ditakhsis dengan panca indara seperti firman Allah surat al-ahqaf ayat 46: تدمر كل شئ ayat ini memiliki makna khusus sebab secara kasat mata ada sesuatu yang tidak rusak diterpa angin seperti langit, bumi dan bendabenda langit, maka dari sisni ayat tersebut telah ditakhsis dengan panca indra atau penglihatan.

b. Ditakhsis dengan akal

Didalam al-Quran memiliki banyak nas-nas yang menjelaskan mentaklifnya (membebani) syara' pada seseorang tanpa melaui proses takhsis akan tetapi akal dapat mentakhsis keumuman ayat tersebut semisal ولله علي الناس حج البيت من السنطاع اليه : firman Allah dalam surat al-Imron ayat 96 سبيلا

$104 \mid$ JURNAL LISAN AL-HAL 
orang seperti anak kecil orang gila namun ayat ini dapat ditakhsis dengan akal bahwa yang hanya mendapat kewajiban melaksanakan ibadah haji tertentu pada orang-orang yang mukallaf saja.

c. Ditakhsis dengan 'urf dan adat

Ada beberapa perangkat yang layak untuk mentkahsis keumuman alQuran yaitu 'urf baik urf quliy maupun urf fi'liy. Contoh dari urf quliy yaitu lafad dirham bilamana dimutlakkan maka cakupannya mata uang yang yang dipakai di suatu daerah, sedangkan contoh urf fi'liy seperti perkataan sayari'aku mengharamkan kamu makan, maka kita cukup melihat kirakira yang menjadi makanan kebiasaan didaerah tersebut apa jika derah itu makanan kebiasannya adalah gandum maka itu yang tidak boleh dimakan. Urf fi'liy menurut Hanafiyah dan Jumhur Malikiyah dapat mentkahsis والولدات : perempuan yang dimaksud disini adalah perempuan yang bukan syarifah sebab perempuan syarifah pada biasanya di di kalangan kaum qurais tidak menyusui ini. akan tetapi menurut pandangannya Syafi'iyah dan Hanabilah ${ }^{24}$ melarang diperbolehkannya al-quran ditakhsis dengan dengan 'urf fi'liy.

d. Ijma'

Ulama memperkenankan mentakhsis lafad-lafad 'am yang terdapat dalam al-quran dengan menggunakan ijma' karena ijma' itu sendiri tergolong qhat'i sedangkan lafad 'am menurut para ulama kecuali imam Abu Hanifah itu dhanniy dengan demikian bilamana antara lafad yang qhat'i dengan lafad dhanniy berkumpul maka yang didahulukan adalah lafad qhat'i. Ibnu Badran mengatakan bahwa yang benar mentakhsis lafad 'am dengan menggunakan dalil ijma' bukan ijma' itu sendiri. ${ }^{25}$

e. Qoul al-Shohabiy

Menurut ulama' Hanafiyah dan Hanabilah qoul al-shohabiy merupakan hujjah syar'iyah dan didahulukan dari pada qiyas dengan alasan bahwa karena sahabat ini langsung mendengar langsung dari Nabi. Akan tetapi menurut Jumhur dari kalangan Syafi'iyah qoul al-Shohabiy tak dapat dijadikan pijakan untuk mentakhsis lafad-lafad yang 'am dengan alasan kadang-kadang perkataan sahabat juga bisa keliru.

f. Takhsis dengan al-Quran atau Sunnah

Sudah menjadi maklum mentaksis dapat diperkenankan dengan alquran sendiri maupun dari hadist Nabi, baik lafad yang mentakhsis itu langsung bersambung dengan lafad 'am atau tidak. contoh mukhassis yang

${ }^{24}$ Abul 'Abbas Syihabuddin, (al-furuq, Juz I, Maktaba Syamilah) , 173.

${ }^{25}$ Muhamad Asy Syaukaniy, (Irsyadu al-Fuhul, Dar al-kutub al-'Arabi, 1999), 141. 
bersambung dengan lafad 'am dalam firman Allah: واحل الله البيع ditakhsis dengan ayat setelahnya وحرم الربا، Sedangkan contoh dari lafad yang mentakhsis itu tidak bersamaan dengan lafad 'am pada firman Allah surat al-baqarah ayat 228: والمطلقات يتربصن بانفسهن ثلاثة قرؤ dari ayat ini mencakup kepada perempuan-perempuan yang hamil dan lainnya, kemudian وأولت :65 ditakhsis dengan ayat yang lain yaitu pada surat al-thalak ayat الاحمال أجلهن أن يضعن حملهن

\section{DAFTAR PUSTAKA}

Wahab Khallaf, Abdul, Ilmu Ushul fiqh, Libanon: Dar al-Ilmi, cet II, 1978. Asy Syarkhasiy , Ushul al-Syarkhasiy, Libanon: Bairut, cet II, 1993, Juz I.

Badruddin, Bahrul Muhith fi Ushul Fiqh, Libanon: Dar al-kutub al-'Ilmiyah, Juz IV, 2000.

Bakar, Abu al-Baihaqi, Sunan Kubra al-Baihaqi, Mekkah: Darl al-Baz, Juz VII, 1994.

Al-Anshariy, Zakariaya, Ghoyatul Wusul, Surabaya: al-Hidayah, 2000.

Hasan bin Muhamad al-'Athar, Hasyiyah al-'Athar, Juz II, Maktaba alSyamilah

Asy Syafi'i, Abu Abdillah , Musnad Asy-Syafi'i, Libanon: Bairut, Juz I, 2001

Muhammad, Aliy al-Amudhiy, al-Ihkam fi Ushulil Ahkam, Libanon: Bairut, cet I, Juz III, 2004.

Asy-Syarkhasiy, Usul al-Syarkhasiy, Libanon: Bairut, Juz I, 1993.

Al-Raziy, al-Mahshul, Libanon: Bairut, Juz I. 2002

Az-Zuhaili, Wahba, Ushul fiqh al-Islami, Libanon: Dar al-Fikr, Juz I. 2005.

'Ali al-Baihaqi, Ahmad bin Husen bin Abu Bakar, Sunan al-Shugra, maktabah al-Dar, Juz I, 1989.

Asy Syaukaniy, Muhamad, Irsyadu al-Fuhul, Dar al-kutub al-'Arabi, 1999.

'Afifī (Al), Abdul Hakim, tt. Mausu'ah Alfi Haditsin Islamiyah. Maktabah Syamilah.

'Athar (Al), Hasan bin Muhamad, tt. Hasyiyah al-'Athar. Maktabah Syamilah.

'Izzuddin bin Abdissalam, tt. Qawaid al-Ahkam fi Mashalihil Anam. Maktabah Syamilah.

Abu 'Abdillah, bin Muhammad bin Hambal, tt. Musnad Ahmad. Maktabah Syamilah.

Ishaq, Abu, al-Kasyaf wal Bayan. Libanon: Bairut. 2002.

Ali bin Abdillah, 1404 H. Al-Ibhaj. Libanon: Birut. 2000.

Alwy al-Maliki, Sayyid, Ibanah al-Ahkam. Bairut: Darul Tsaqofah al-

106 JURNAL LISAN AL-HAL 
Islamiyah. tt.

Amudhī (Al), Aliy Muhammad, Al-Ihkam fi Ushulil Ahkam. Libanon: Bairut. 2004.

Astqhalany (Al), Ibnu hajar, Fathul Bariy. Bairut: Darul Ma'rifat. tt.

Badruddin, Bahrul Muhith fi Ushul Fiqh. Libanon: Dar al-Kutub al-'Ilmiyah. 2000.

Baihaq (Al), Manaqib al-Imam Syafi'i. Libanon: Darul Fikr al-Islam. tt.

Baihaqī (Al), Abu Bakar, Sunan Kubra al-Baihaqi. Mekkah: Dar al-Baz. 1994.

Farj (Al), Abu, Jami' al-Ulm wa al-Hikam. Bairut: Dar al-Ma'rifat. 1408 H.

Hamdah, Faruq, Dalil al-Roghibin Ila Riyadh as-Shalihin. Bairut: Darul Tsaqafah al-Islamiyah. 1988.

Khallaf, Abdul Wahab, Ilmu Ushul fiqh. Mesir: Dar al-Qhalam. 1978.

Ma'luf, Louis, al-Munjid fi-al-Lughah wa al-'Alam. Bairut: Maktabah Dar alMasyriq. 1987. 
"Kaidah Ushuliyah Lughawiyah"

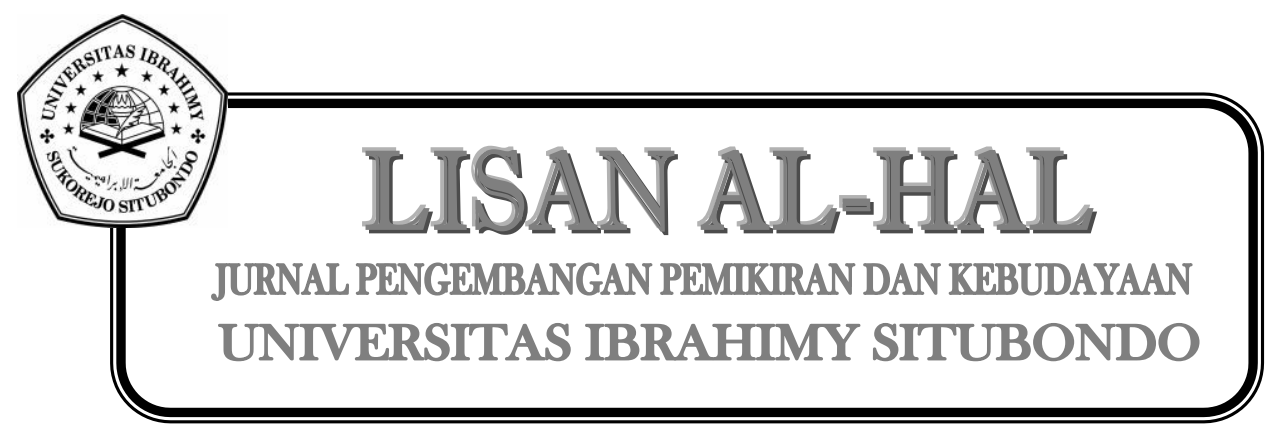

108 JURNAL LISAN AL-HAL 